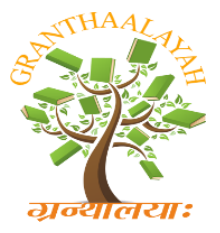

INTERNATIONAL JOURNAL OF RESEARCH GRANTHAALAYAH

A knowledge Repository

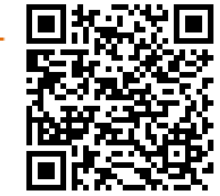

\title{
CHANGING BUSINESS TRENDS FOR ENVIRONMENT PROTECTION
}

\author{
Jaya Sharma
}

Govt. Girls college sehore (M.P.)

\begin{abstract}
Businesses have been adopting every possible way to minimize their manufacturing cost in order to maximize their profit. Previously it was not a matter of concern for businesses to opt for some specified way of manufacturing, producing, marking and or packing so that the harmful impact on environment can be stopped. With the passing of time we are witnessing a world full of environmental problems like pollution, impure drinking water, poisonous crops and edibles. A huge amount of wastes is available everywhere to harm our earth in many ways may it be air, water of land. Thus there seems an urgent need to take some steps that may help to lessen such hazardous impacts on our environment. As business are an important part of our world it becomes a moral responsibility of all manufactures, industrialists and marketers to adopt the changing trends in their business which can help preventing our environment. The present paper tries to discuss some issues that are linked with finding out some new trends in business marketing and also suggests some views regarding better managements of waste material.
\end{abstract}

Keywords:

Green marketing, environment, green products, responsibility, fair waste.

\section{INTRODUCTION}

As an important factor of economic growth businesses have developed at a high speed in last few decades. In India also government has taken various initiatives to improve industrialization in order to increase production and provide employment. As a result we can see huge industrialization all over the country and also the impact rose due to it in some positive ways and some negative ways. The positive effects are very few and can be counted on figures like it has increased the availability of many things in the country at a lower price and it has also given employment opportunities to our skilled and unskilled labour. But, the negative effects are endless in the form of air pollutions due to the emission of poisonous air, water pollution through discharge of untreated wastewater in various natural water recourses, land pollution through the leakage of toxic liquids from industries, use of pesticides and other pest control products, noise pollution through loud noises, radiation and many more.

In last few decades as the world is facing various environmental problems these environmental issues have gained attentions in business and social life. Thus the trends of business are changing specially in marketing the product because the manufacturing process is governed by some laws which take care of it but the marketing procedure ultimately depends upon the businesses. It is apparent from the current business marketing world that the term "Go Green" is rapidly capturing market. The consumer is aware about the environmental impact of the product he/she is buying 
and thus the companies have to rethink about their marketing strategy and relate it with the green concept.

As the companies have understood the importance of getting green they are adopting ways like, green product and green marketing to stay in the competition and remain in the market. They need to take appropriate green strategies in their working activities like production or marketing. In this way both the marketer and consumers are focusing on adoption of green techniques. From companies perspective this conversion from traditional trends of production and marketing to the new green trends of production and marketing may be cost consuming for some years but in the long run it is going to save their cost.

Green marketing is the process of selling products and/or services on the basis of their environmental and ecological benefits. Such a product or service may itself be an environmentally friendly product or service, or it may be produced and/or packaged in a manner which is considered to be environmentally friendly. We can assume that consumers will view the "greenness" of a product or service's as a benefit and so their buying decisions will be based on this aspect.

Green Marketing According to M. J. Polonsky and P. J. Rosenberger (2011) has been defined as, "All activities designed to generate and facilitate any exchanges intended to satisfy human needs or wants such that the satisfaction of these needs and wants occurs, with minimal detrimental impact on the natural environment". Environmental or green marketing practices as a result of compulsion due to legislative pressures and pressures of environmental groups have changed to genuine efforts to behave in an eco-responsible manner and improve sustainable marketing plans (Polonsky and Rosenberger, 2001). The concept green marketing affects the buying behavior of consumers. According to D"souza (2005), advertising terms such as "environmentally friendly, recyclable, biodegradable, and ozone safe" are often seen regularly in green advertisements and consumers are seldom exposed to such messages effectively.

The companies can adopt various methods of making consumers aware about the environmental benefits of their products and make their profit, but the results from various surveys show that not many customers actually know the difference in traditional and green products. At the same time a majority of customers even do not care about mother earth they find it easy to even adversely affect it. At some places companies are finding it difficult to go green as they need to sometime develop an additional research and development cell in order to check their products and marketing techniques. These are some issues which are responsible for lower growth and acceptance of green marketing. It is our duty to spread awareness about environmental protection and putting every possible step to prevent it. Even if we need to pay a little more we should go ahead as it is for the sake of our coming generation.

To suggest some steps in protecting the environment the present study finds that new business ideas should be initiated in the form of collecting the packaging materials waste (further referred as fair waste) from the consumers in the form of soap cover, bottles, cane etc. that can be reused if treated properly without putting a huge amount of the same. We found in everyday life that people throw such waste in open and then it becomes a part of common waste which runs throw a long procedure for its recycle. We can make some collection counters or the same selling points can also work for collecting the fair waste (waste that can be treated as reusable with little efforts). The present study has come up with following suggestions:

- Need for a shift in the consumer's behavior and attitude towards more environmental friendly life styles.

- Creating some collection Agencies to collect the fair waste from customers.

- Some Smart Cards should be initiated to maintain the points based on fair waste deposited. 
- Self -Help Group should be taken in for help they can work for collecting the fair waste from houses and other placed. They can directly supply it to the collection agencies.

- The following model can be applied

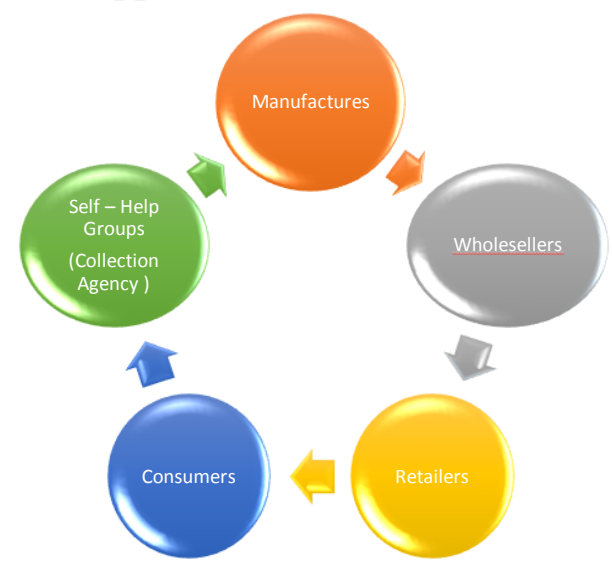

Figure 1: Model for fair waste management

Following benefits can arise from the above implications.

- IT will initiate the concept of Recycling, Reduce, Reuse

- Sustainable Environment

- Poverty Irradiation

- Women Empowerment

- Utilization of self help group system of society

- Cleanliness and Hygienic condition

- CSR for Company

\section{CONCLUSION}

As the environment is an essential part of our life we cannot take it for granted anymore some efforts need to be taken and maintained for this. The green marketing is a positive step from businesses in this regard which needs to be constantly put on from all sectors of the society. Policies should be made to make people aware about it. It is true that the new trend of green marketing is not easy to apply but if properly explained and adopted the results can be surprising. Businesses should provide their best efforts to develop green products and promote green marketing. The present paper has come up with a suggestion of creating some fair waste collection agencies in order to make a new cycle for eradicating the problems regarding proper collection of waste. This can not only help in proper treatment of waste but it is going to make some new areas for the self-help groups and collection agencies which will work for it.

\section{REFERENCES}

1. Bhatia and Jain: Green Marketing: A Study of Consumer Perception and Preferences in India. Electronic Green Journal, 1(36)

2. D'Souza, C. (2005). Green advertising effects on attitude and choice of advertising themes. Asia Pacific Journal of Marketing and Logistics, Vol. 17 No.3, pp.51-66.

3. " GREEN MARKETING: A STUDY ON INDIAN YOUTH” available at http://www.facultyjournal.com/ by Aditya Maheshwari and Dr. Gunjan Malhotra 
4. “ Green Marketing: A Study of Consumers' Attitude towards Environment Friendly Products" http://dx.doi.org/10.5539/ass.v8n12p11

5. Magali Morel \& Francis Kwakye, “ Green marketing: Consumers' Attitudes towards Ecofriendly Products and Purchase Intention in the Fast Moving Consumer Goods (FMCG) sector" thesis submitted by students of Umea School of Business

6. Mendleson, N. (1994). Environmental marketing business partnering at AFC-developing strategic alliances, environmental marketing: critical success strategies for reaching the green consumer. Proceedings of the 1994 Conference, Sydney, 22-23 February, pp.87-103.

7. Polonsky, M. J. \& Rosenberger, P. J. (2001). Reevaluating green marketing: a strategic approach. Business Horizons, 44(5), pp 21-30.

8. Polonsky, M. J. (2011). Transformative green marketing: Impediments and opportunities. Journal of Business Research, 64(12), pp 1311-1319.

9. Rahul Argha Sen," A Study of the Impact of Green Marketing Practices on Consumer Buying Behaviour in Kolkata International Journal of Management and Commerce Innovations ISSN 2348-7585 (Online) Vol. 2, Issue 1, pp: (61-70), Month: April 2014 September 2014, Available at: www.researchpublish.com 